\title{
$\begin{array}{lllllllll}\mathrm{I} & \mathrm{N} & \mathrm{S} & \mathrm{T} & \mathrm{I} & \mathrm{T} & \mathrm{U} & \mathrm{T} & \mathrm{E}\end{array}$
}

\section{Wives as Breadwinners: Wives' Share of Family Earnings Hits Historic High during the Second Year of the Great Recession}

$\mathrm{T}$ The National Bureau of Economic Research (NBER) recently stated the official end of the Great Recession was June 2009, yet American families continue to experience the pain of massive job loss and slow job recovery. The final toll of the Great Recession on families is still unknown, with family poverty rates rising for the past two consecutive years to the highest level recorded in the past fifteen years and family income levels falling. ${ }^{1}$

\section{Increased Reliance on Employed Wives' Earnings}

One consequence of the recession for many families is a greater reliance on wives' earnings. As husbands lose their jobs, family earnings plummet, and the role of wives' earnings often becomes critical to keeping families afloat.

In 2009, employed wives contributed 47 percent of total family earnings, a statistically significant rise from 45 percent in 2008 - and the largest single-year increase during the past fifteen years (see Figure 1). And these changes affect families with children under age 18 as well, where the economic contribution made by employed mothers also increased.

Figure 1 illustrates how the Great Recession has substantially accelerated the trend of an increased reliance on employed wives' earnings. From 1995 to 2007 (a thirteen-year period), employed wives' share of total family earnings grew by four percentage points. In contrast, from 2007 to 2009 (the two years of the recession) employed wives share grew by three percentage points. Almost half of the total increase over the past fifteen years occurred during the Great Recession.

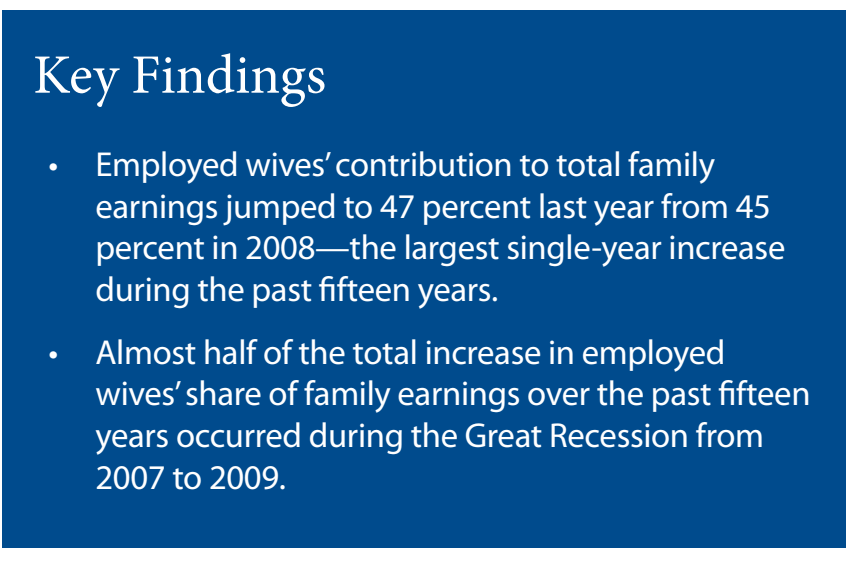

FiguRE 1. EMPLOYED WIVES' PERCENT CONTRIBUTION TO TOTAL FAMILY EARNINGS, 1995-2009

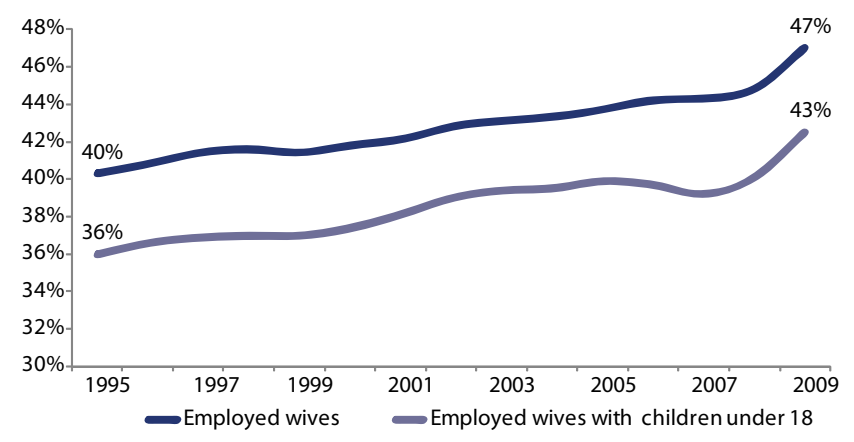

Source: 1996-2010 Current Population Survey, Annual Social and Economic Supplements

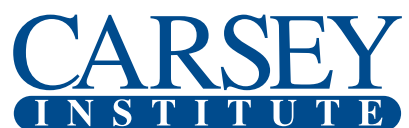

BUILDING KNOWLEDGE FOR FAmilies AND Communities
Huddleston Hall, 73 Main Street, Durham, NH 03824

(603) 862-2821 • www.carseyinstitute.unh.edu

This work was supported by the Annie E. Casey Foundation, the W. K. Kellogg Foundation, and an anonymous donor.
UNIVERSITY

of NEW HAMPSHIRE 


\section{Wives' Increased Contribution due to Husbands' Unemployment}

This large increase in wives' contribution to family earnings is not due to a large increase in wives' earnings (in fact, the median earnings of employed wives decreased from $\$ 31,041$ in 2007 to $\$ 30,000$ in 2009) but rather to a decrease in husband's employment and, in turn, earnings. Husbands of employed wives were less likely to be employed and more likely to be looking for work in 2009 compared with 2007 (see Figure 2). The percentage of employed wives with an employed husband decreased from 86 percent to 81 percent over the recession. In 2009, 7 percent of husbands of employed wives were looking for work, up from only 3 percent in 2007. High unemployment among men translates into a decrease in the median earnings of husbands of employed wives from $\$ 46,562$ to $\$ 42,000$ during the recession (in 2009 dollars).

Job loss and unemployment has been particularly high among African American men and men with less education, and in both cases wives contribute more than half of total family earnings in 2009 ( 55 percent and 58 percent, respectively), an increase for both from 2007.

\section{Implications of Increased Reliance on Wives as Breadwinners}

The massive job loss over the eighteen months of the recession, primarily in male-dominated industries, such as manufacturing and construction, has left many families with lower earnings and has placed an unprecedented importance on wives' earnings to keep families afloat. It is likely that wives will remain in the labor force even after their husbands return to work, as many families have lost ground due to diminished savings, housing values, and retirement accounts. Thus, it is critical to pay attention to the implications of wives' as breadwinners for families and the workplace. As more wives enter the labor force and earn wages comparable to their husbands, gender roles can change for both women and men.

Families that experience male job loss and reduced earnings are stressed. Even prior to the recession, working families were feeling work and family stress due to increased time spent working, inflexible workplaces that have not kept pace with changing families, and the lack of policy supports. Policies to support working families, such as paid sick leave and paid family medical leave, affordable quality child care, livable wages, and measures that increase workplace flexibility, could help reduce the work and family conflict that many men and women experience. Additionally, there is an obvious need for the creation of new jobs, continued support for long-term unemployment, and expanded public assistance and food stamps to help families during this economic recovery.

Employed wives contribute almost half of family earnings, drawing attention to equity in the workplace. Women employed full-time year-round earn 77 percent of what
FiguRE 2. HUSBANDS' EMPLOYMENT STATUS, 1995-2009

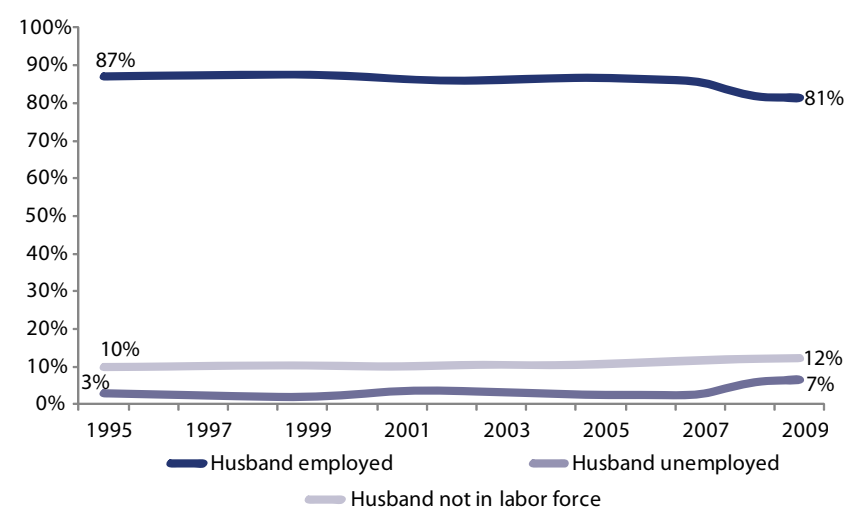

Note: Employment status is of husbands of employed wives.

Source: 1996-2010 Current Population Survey, Annual Social and Economic Supplements.

corresponding men earn. ${ }^{2}$ Clearly, family economic stability depends on wives' economic contributions, and families suffer when women earn less.

\section{Data Used}

This fact sheet uses data from the U.S. Census Bureau's Current Population Survey (CPS) March Supplements from 1996 to 2004 and Annual Social and Economic Supplements (ASEC) from 2005 to 2010. "Wives' contribution to total family earnings" is the ratio of wives' annual earnings to the sum of wives' and husbands' annual earnings. Comparisons presented in the text are statistically significant at the 0.05 level.

\section{EN D N O T ES}

1. Carmen DeNavas-Walt, Bernadette Proctor, and Jessica Smith, "Income, Poverty, and Health Insurance Coverage in the United States: 2009" (Washington, DC: U.S. Census Bureau, 2010).

2. Carmen DeNavas-Walt, Bernadette Proctor, and Jessica Smith, "Income, Poverty, and Health Insurance Coverage in the United States: 2009."

\section{A C K N O W L E D G M E N T S}

The author thanks Marybeth Mattingly and Mil Duncan at the Carsey Institute and Rebecca Glauber at the University of New Hampshire for their thoughtful comments and suggestions; Michelle Stransky for research assistance; and Terri Rippett and Amy Sterndale for publications support.

\section{A B OUT THE AUTHOR}

Kristin Smith is a family demographer at the Carsey Institute and a research assistant professor of sociology at the University of New Hampshire (kristin.smith@unh.edu).

\section{* Corrections were made to the percentage of what women} employed full-time year-round earn and Endnote 2. 